\title{
Growth Space Requirements Models for Daniellia Oliverii (Rolfe) Hutch and Daviz Tree in Makurdi, Nigeria
}

\author{
Dau, J. H. ${ }^{1^{*}}$, Vange, $\mathrm{T}^{2}$ \& Amonum, J.I ${ }^{1}$ \\ ${ }^{1}$ Department of Forest Production and Products, University of Agriculture, Makurdi-Nigeria. \\ ${ }^{2}$ Department of Plant Breeding and Seed Science, University of Agriculture, Makurdi-Nigeria. \\ *daujaphson@gmail.com
}

\begin{abstract}
There is generally lack of emphasis on effective management of natural forest in Nigeria. These have led to decline in the natural forest areas while some economic trees are gradually becoming extinct. Studies on growth space requirements for the trees are generally lacking and inventory information is scarce in the southern guinea savanna of Nigeria. Growing space was associated with crown size. Therefore, crown and stem diameter relationship models were tested on data recorded from D. oliverii (Rolfe) Hutch and Daviz trees in Makurdi. The study area was divided into nine hectare blocks, i.e. a total of nine blocks as sample plots (sizes $100 \times 100$ meters each) which was randomly laid down. Simple random sampling technique was used to collect data on tree height, diameter at breast height (dbh), diameter at the base, middle, top (with the use of diameter tape and a portable ladder) and crown diameter (with the use of 30 meter measuring tape) within the study area. The data collected on trees $>10 \mathrm{~cm}$ dbh were tested on seven models on crown diameter and stem diameter relationship. The linear model provided the best model fitted with R2 values of 0.799\%. For optimum planting, fast growth and high production/yield the tree would require a planting spacing of $4 \times 4$ meters. The results shows, a dominant free-growing tree of diameter $48.7 \mathrm{~cm}$ diameter tree would require 0.0060 hectare of growing space with a stocking of 168 trees per hectare. Stand basal area (density) converges around 0.000055 $\mathrm{m} 2,0.000038 \mathrm{~m} 2$ and $0.000013 \mathrm{~m} 2$. The baseline information provided by this study could serve as a guide for optimum planting distances and tree density in large scale plantations establishment.
\end{abstract}

Keywords: Crown diameter; bole diameter; growth space; models; predict/estimate; stocking.

\section{INTRODUCTION}

Crown and bole diameter relationship is particularly useful for predicting or estimating growth space, stand density and limiting stocking relationships (GOELZ, 1996; KIGOMO, 1991, 1998). The growth of a tree depends to a large extent on the tree crown variables. Tree crown size can determine tree growth and survival; tree height and crown dimension determine length of its clear bole, which is important in marketing of the tree into various wood products (Smith, 1986). Tree crown diameter relationship is well correlated with tree bole diameter (GERING and MAY, 1995; KIGOMO, 1998; LOCKHART et al., 2005; HEMERY et al., 2005).

KOZIOWSKI et al., (1991), reported that the crown of a tree refers to the totality of the tree above ground, including stems, leaves and reproductive structures. A tree's crown is that section(s) of a tree bearing live branches and foliage (HELMS, 1998; LOCKHART et al., 2005). Measurements of crowns are important in quantifying and qualifying plant health, growth stage and efficiency. Crown shape represents the physical space a tree utilizes for growth as modified by the physical environment (BECHTOLD, 2002).

The prediction of growing space, require biologically plausible models to determine stand density and stocking of the trees. For this purpose and its goal to be achieved, models on growing space requirement are very crucial and are essential for forest managers and planners. There is lack of information on inventory and growth space of economic tree species in Nigeria for sustainable management.

The aim of this study, was to predict planting spacing require for growth and to find ways of improving production per unit area through stand density control; also, to provide baseline information and a guide for optimum planting distance and possible tree stocking per hectare to control competition among Daniellia oliverii (Rolfe) Hutch and Daviz trees and enhance growth for sustainable management of indigenous tree (such as Daniellia oliverii (Rolfe) Hutch and Daviz) plantations for present and future uses. 


\section{MATERIALS AND METHODS}

\subsection{The Study Area}

The study was carried out on Daniellia oliverii (Rolfe) Hutch and Daviz in Makurdi, Nigeria which lies between longitude $8^{\circ} 21^{\prime}$ and $9^{\circ} \mathrm{E}$ and latitude $7^{\circ} 21^{\prime}$ and $8^{\circ} \mathrm{N}$ in Benue State, within the southern guinea savanna ecological zone (AGERA et al., 2011; AJAERO, 2007; UAM 1989). One important feature is the presence of the River Benue which divides the town into the northern and southern parts. The climate of the area is tropical sub -humid climate with high temperatures and high humidity ; the average maximum and minimum daily temperature of $35^{\circ} \mathrm{C}$ and $21^{\circ} \mathrm{C}$ in wet season, and $37^{\circ} \mathrm{C}$ and $16 \mathrm{C}$ in dry season (SEIBERT, 2007). Benue state has boundaries to the south with Enugu and Cross River states, to the east with Taraba state, north with Nasarawa state and west with Kogi state. The climate is characterized by distinct rainy and dry seasons. The mean annual rainfall is 1200 to 1500 $\mathrm{mm}$. The vegetation of the area has been described as Southern guinea savanna (UAM physical planning manual, 1989). The major occupations of the people include; farming, civil service, trading and hunting; and the major tribes are Tivs, Idoma and Igede.

\subsection{Data Collection (Measurement Procedures)}

Daniellia oliverii (Rolfe) Hutch and Daviz tree was selected based on its economic values to Makurdi community. Data from D. oliverii (Rolfe) Hutch and Daviz trees were collected in Makurdi, Nigeria. Trees were sampled from nine hectare land which was divided into nine blocks as sample plots (sizes $100 \mathrm{~m}$ x 100m each) which was randomly laid down. Simple random sampling technique was used for data collection; trees greater than $10 \mathrm{~cm}$ diameter at breast height (dbh) were assessed. Complete enumerations of tree species in the nine blocks was carried out and the measurements of the parameters of interest were taken; bare forest areas were excluded. The data collected on every tree species includes: crown diameter by using 30-meter measuring tape; dbh, diameter at the base, diameter at the middle, diameter at the top. Diameter of the sampled trees was determined with the use of diameter tape on winding the tape around the tree at 1.3 meters above the ground on the uphill side of the tree; while total height was measured by the used of Haga altimeter.

Crown-diameter measurement was based on the assumption that the vertical projection of a tree crown is circular; four radii were measured (using 30-metre measuring tape) and in the direction forming equal angles (FOLI et al., 2003; ZUHAIDI, 2009). Along each radius of the tree crown, the diameter tape was held horizontally and extended until each person was vertically under the tip of the longest branch on both sides; a 3.00 - meters ranging pole was used to align vertically to the edge of the crown (KIGOMO, 1991, 1998). The diameter tape was turned by $90^{\circ}$ and measurements were carried out repeatedly along the thinnest part of the tree crown and recorded (FOLI et al., 2003). Average crown diameter $(\mathrm{Cd})$ was calculated by summing up the four radii and divided by 2 , thus;

$$
\mathrm{Cd}=\sum \mathrm{ri} / 2 \quad \text { Equation [1] }
$$

Where $\mathrm{Cd}=$ average crown diameter; $\mathrm{ri}$ = projected crown radii measured on four axes

Dbh over bark was measured at 1.3 meters above the ground for all individual tree $\geq 10 \mathrm{~cm}$ by means of diameter tape. The points of the measurement were taken from the uphill sides of the trees and on the inside of the lean for leaning trees (ZUHAIDI, 2009). For trees with deformations at $1.3 \mathrm{~m}$, the measurement was made at the sound point on the stem above the abnormality. During the measurement, loose bark, climbers and epiphytes were lifted above the measuring tape; this was to avoid measurement errors and reading.

\subsection{Data Analyses}

\section{Basal Area}

The dbh was used to compute basal area using the formula:

$$
\text { B.A }=\pi \mathrm{D}^{2} / 4 \quad \text { Equation [2] }
$$

Where: $B A=$ Basal area (hectare); $D=$ Diameter at breast height $(m)$ and $\pi=3.142$

The trees within each one hectare block were grouped and their basal area summed together to obtain the basal area per hectare.

\section{Crown-Diameter}

The data collected from the field were fitted to the following model forms for predicting crown diameter suggested by different authors with the aim of choosing the model form that showed the best ability to stabilize the variance in the data: 
Growth Space Requirements Models for Daniellia Oliverii (Rolfe) Hutch and Daviz Tree in Makurdi, Nigeria

\begin{tabular}{|c|c|c|}
\hline $\mathrm{Cd}=\mathrm{b}_{\mathrm{o}}+\mathrm{b}_{1} \mathrm{dbh}+e i$ & Equation (4) & (LOCKHART et al., 2005) \\
\hline $\mathrm{Cd}=\mathrm{b}_{\mathrm{o}}+\mathrm{b}_{1} \mathrm{dbh}^{2}+e i$ & Equation (5) & (FOLI et al., 2003) \\
\hline $\mathrm{Cd}=\mathrm{b}_{\mathrm{o}}+\mathrm{b}_{1} \mathrm{dbh}+\mathrm{b}_{2} \operatorname{lndbh}+e i$ & Equation (6) & - \\
\hline$C d=b_{o}+b_{1} \operatorname{lndbh}+e i$ & Equation (7) & (ZUHAIDI 2009) \\
\hline $\mathrm{LnCd}=\mathrm{b}_{0}+\mathrm{b}_{1} \mathrm{dbh}^{2}+\mathrm{b}_{2} \mathrm{Lndbh}^{2}+e i$ & Equation (8) & (FOLI et al., 2003) \\
\hline $\operatorname{LnCd}=b_{o}+b_{1} \operatorname{lndbh}+e i$ & Equation (9) & - \\
\hline $\operatorname{LnCd}=\mathrm{b}_{\mathrm{o}}+\mathrm{b}_{1} \mathrm{dbh}^{2}+\mathrm{b}_{2} \operatorname{Lndbh}+e i$ & Equation (10) & (ZUHAIDI, 2009) \\
\hline
\end{tabular}

\section{Crown Area (Growth Space)}

Using the calculated crown diameter $(\mathrm{Cd})$, the crown area (A) was estimated and expressed in hectare basis (conversion of crow diameter in meters to area in hectares):
$\mathrm{A}=\left(\pi \mathrm{Cd}^{2} / 4\right) / 10,000$
Equation (11)

Where: $A=$ growing space/area $; \boldsymbol{C d}=$ crown diameter $; \pi=3.142$

$\mathrm{N}=1 /$ A i.e. $\left[1 /\left(\mathrm{Cd}^{2} / 4\right) / 10,000\right]$

Equation (12) (KUNLUVAINEN, 1991; PHILLIP, 1994)

Where: $N=$ stock; $A=$ growing space

\section{Stand Density/ Basal Area Per Hectare}
$\mathrm{S} . \mathrm{D}=\pi \mathrm{D}^{2} / 40,000$
Equation (13)
(ZUHAIDI, 2009)

Where: $S . D=$ Stand density; $D=$ diameter at breast height; $\pi=3.142$.

\section{Criteria for Model Formulation and Ranking}

The models were formulated in a form suitable for use in a forest management system; also, it should be easily used and speedy in execution time. They were fitted and assessed; the assessment was based on all the following criteria: the significance of regression equation (F-ratio), coefficient of determination $\left(\mathrm{R}^{2}\right)$, root mean square error (RMSE) and normal probability plots of residuals (ONYEKWELU, 2005).

The best model was selected based on a ranking procedure, for each model ranking was based on the above mentioned criteria. The model with the highest F-ratio/ $\mathrm{R}^{2}$ was assigned a rank of one while model with the lowest F-ratio/ $\mathrm{R}^{2}$ was assigned a rank of seven; the model with best fitted residual/normal probability plots and lowest RMSE was assigned a rank of one. Then the rank for $\mathrm{R}^{2}$, RMSE, F-ratio, residual and normal probability plots were combined, and were then summed to determine the most appropriate model (KOZAK and SMITH, 1993; MOHAMED and AHMED, 2014).

\section{RESUlTS}

The results of crown diameter and bole diameter distributions of the tree species from the study area are shown in Figure 1; it ranged from $15.00-61(\mathrm{~cm})$ for bole diameter and 3.00-11.00 (m) crown diameter.

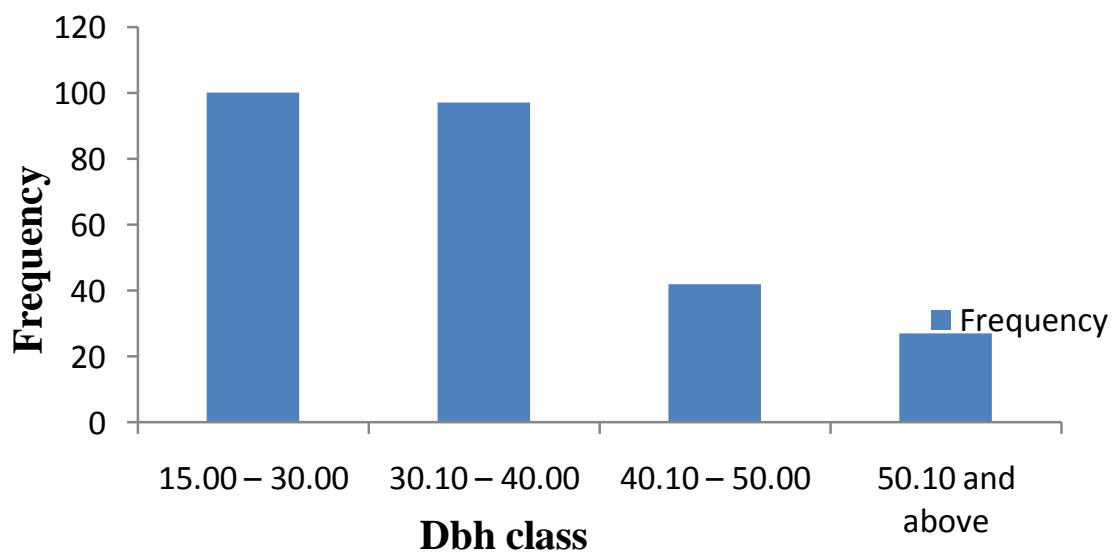

Figure 1. Bole-diameter Distributions of Daniellia oliverii (Rolfe) Hutch and Daviz in Makurdi-Nigeria 


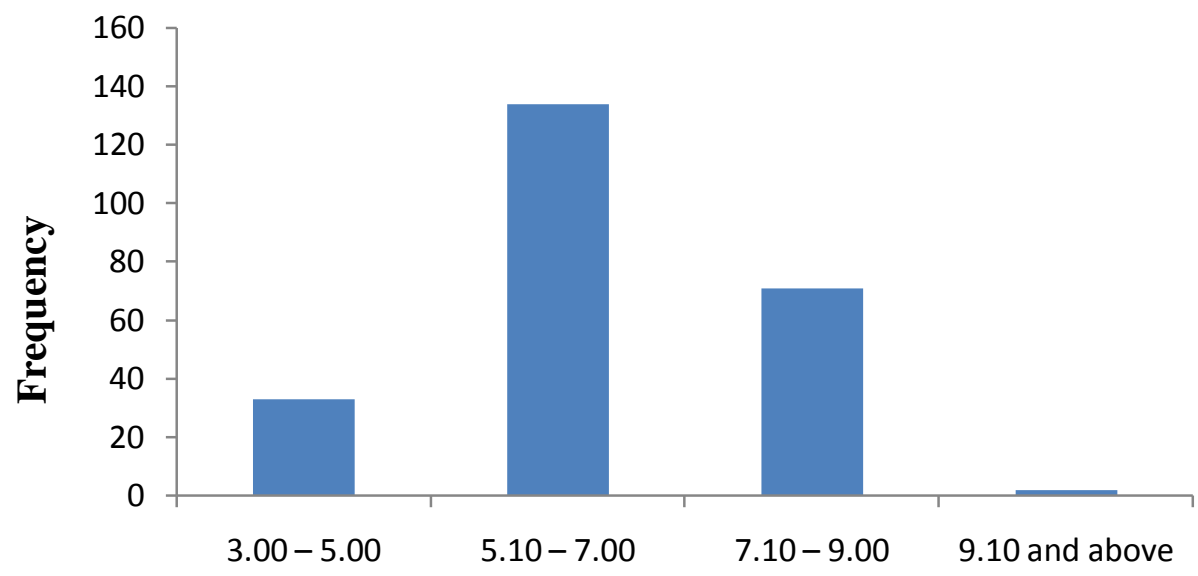

Crown class

Figure 2. Crown-diameter Distributions of Daniellia oliverii (Rolfe) Hutch and Daviz in Makurdi-Nigeria

Table 1, shows the result of the descriptive statistics (i.e. the mean, standard error, standard deviation, co-efficient of variation, minimum and maximum of each growth variable) of data collected on growth variables (characteristics) for the species. The mean stem diameter was $35.38(\mathrm{~cm})$ with 20.6 and $77.2(\mathrm{~cm})$ found to be the minimum and maximum bole diameter of the tree species, respectively. The mean crown diameter of the tree species was estimated to be 6.81 metre with 3.10 and $10.8(\mathrm{~m})$ as the minimum and maximum; from the result the mean B.A and was predicted using the mean $\mathrm{dbh}$ and crown diameter (Table 1)

Table 1. Descriptive Statistics for Daniellia oliverii Tree Species in Makurdi-Nigeria

\begin{tabular}{cccccccc}
\hline $\mathbf{N}$ & Variables & Mean & SE & S. Dev. & C. V\% & Min. & Max. \\
\hline 266 & DBH & 35.38 & 0.63 & 10.20 & 28.8 & 20.6 & 77.2 \\
& CD & 6.81 & 0.10 & 1.62 & 23.8 & 3.10 & 10.8 \\
& B.A & 0.11 & 0.0042 & 0.0679 & 63.2 & 0.0333 & 0.4681 \\
\hline
\end{tabular}

DBH $=$ Diameter at breast height $(\mathrm{cm}), C D=$ Crown diameter $(m), B A=$ Basal area $\left(m^{2}\right), \operatorname{VOL} .=\operatorname{Volume}\left(\mathrm{m}^{3}\right)$. Mean interval $= \pm$ standard error.

Table 2, summarized the regression parameter for the tree species. Coefficients of determination $\left(\mathrm{R}^{2}\right)$ ranged from 0.754 to 0.803 Daniellia oliverii. RMSE was used to compare untransformed models while F.I used to compare the transformed models as showed in the Table.

Table 2. Summary of regression parameters for Daniellia oliverii (Rolfe) Hutch and Daviz Tree in Makurdi, Nigeria

\begin{tabular}{ccccccc}
\hline $\begin{array}{c}\text { Model } \\
\text { No. }\end{array}$ & Model type and model coefficients & $\mathbf{R}^{\mathbf{2}}$ & Adj. $\mathbf{R}^{\mathbf{2}}$ & $\mathbf{R M S E}$ & F-ratio & FI \\
\hline$[4]$ & $C d=1.743+0.143 d b h$ & 0.799 & 0.801 & 0.7176 & 1043.95 & - \\
{$[5]$} & $C d=4.514+0.002 d b h^{2}$ & 0.757 & 0.756 & 0.7884 & 819.9 & - \\
{$[6]$} & $C d=-1.046+0.053 d b h+0.477 \ln d b h$ & 0.803 & 0.801 & 0.7118 & 533.3 & - \\
{$[7]$} & $C d=-12.282+5.407$ lndbh & 0.796 & 0.795 & 0.7231 & 1.024 & - \\
{$[8]$} & $L n C d=0.340+-0.007 d b h^{2}+0.143$ Lndbh $h^{2}$ & 0.755 & 0.754 & 0.1159 & 404.58 & 0.0514 \\
{$[9]$} & $L n C d=-0.826+0.770 \operatorname{lndbh}$ & 0.754 & 0.753 & 0.1161 & 805.69 & 0.0514 \\
{$[10]$} & $L n C d=-0.870+-4.769 d b h^{2}+0.784$ Lndbh & 0.754 & 0.752 & 0.1163 & 401.37 & 0.0515 \\
\hline
\end{tabular}

$d b h=$ Diameter at breast height $(\mathrm{cm}) ; R^{2}=$ Coefficient of Determination; RMSE = residual mean square error; FI=furnival index.

The statistical T-test paired for observed and predicted values using the best fitted models to test for significant difference at $\mathrm{p}<=0.05$ level; the best fitted models were validated. The fitted linear model was not significant at 0.05 levels. The tree species predicted crown diameter from bole diameter with value $p>0.05$ level of significance (see Figure 3 ). 
Growth Space Requirements Models for Daniellia Oliverii (Rolfe) Hutch and Daviz Tree in Makurdi, Nigeria

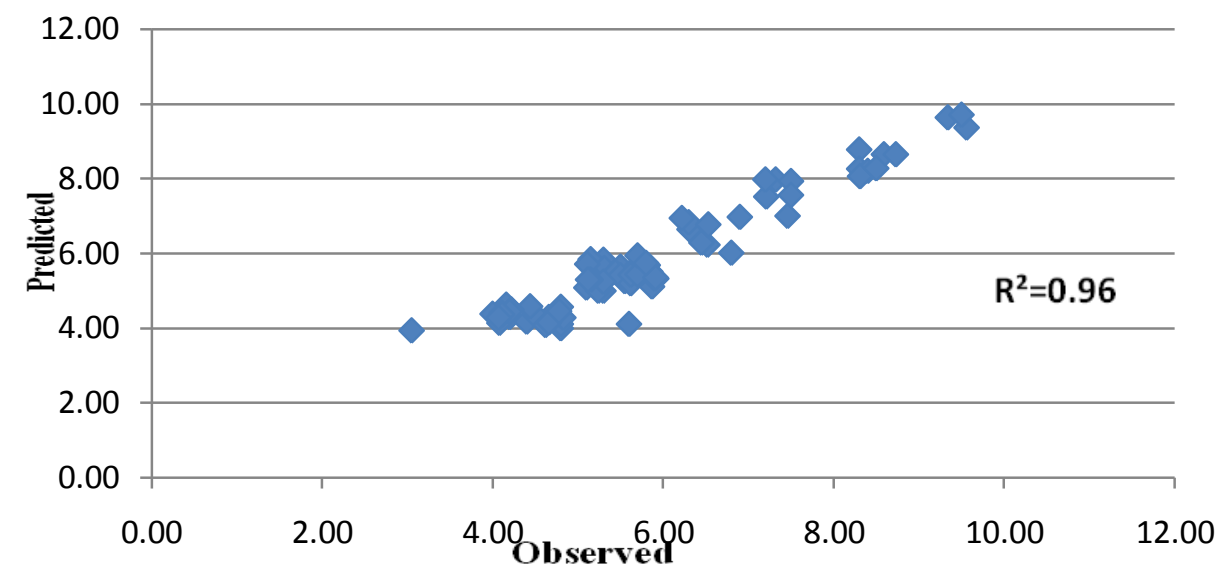

Figure 3. Relationship between Predicted and Observed values for Daniellia oliverii (Rolfe) Hutch and Daviz Trees in Makurdi-Nigeria

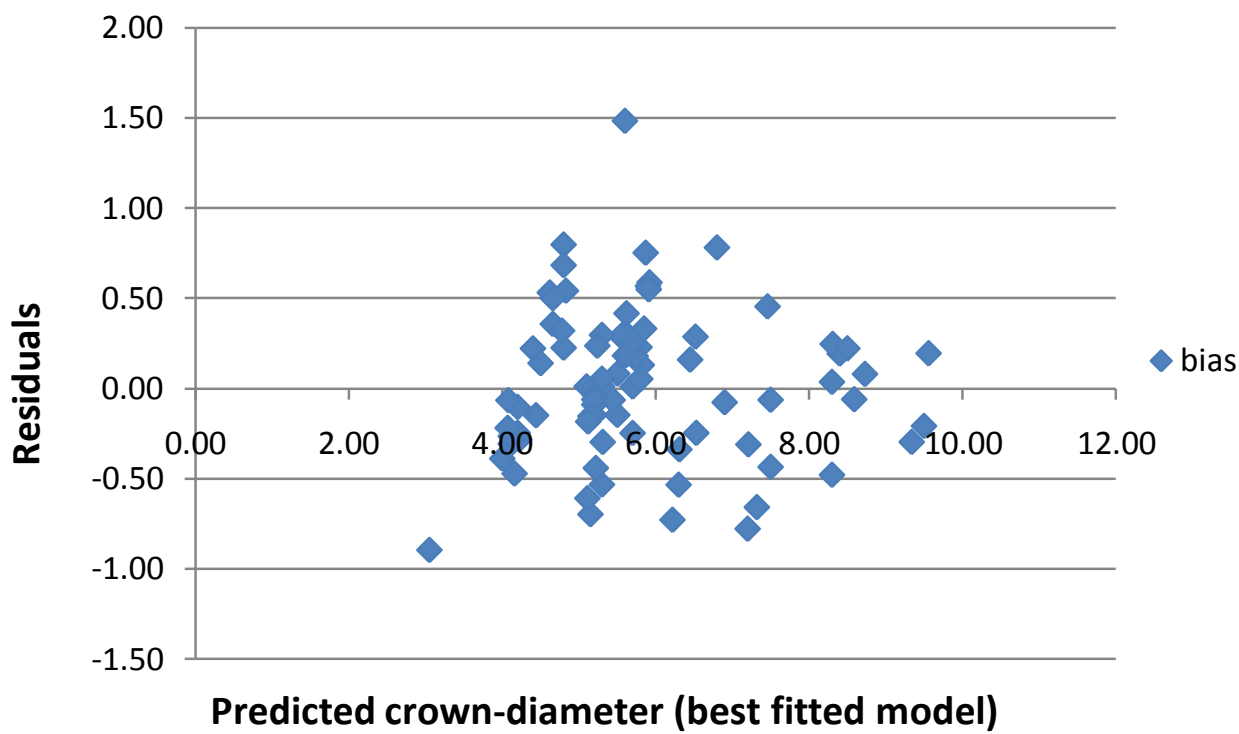

Figure 4. Scatter plot of Residuals and Predicted crown-diameter for Daniellia oliverii (Rolfe) Hutch and Daviz Trees in Makurdi-Nigeria

Table 3. Predicted crown diameter (cd), Growing space (S), Stocking (N) and Stand density (D) from the modeling (model 4) for Daniellia oliverii (Rolfe) Hutch and Daviz Tree in Makurdi-Nigeria

\begin{tabular}{cccccc}
\hline $\mathbf{D b h}(\mathbf{c m})$ & $\mathbf{C d}(\mathbf{m})$ & $\mathbf{C d} / \mathbf{d b h}$ & $\mathbf{S ~ ( h a )}$ & $\mathbf{N h a}^{\mathbf{- 1}} \mathbf{( 1 / S )}$ & $\mathbf{D}\left(\mathbf{m}^{\mathbf{2}} \mathbf{h a} \mathbf{- 1}^{\mathbf{1}}\right)$ \\
\hline 18.70 & 3.79 & 0.203 & 0.0012 & 800 & $4.609^{05}$ \\
25.10 & 5.16 & 0.206 & 0.0022 & 448 & $4.949^{06}$ \\
30.80 & 6.46 & 0.210 & 0.0030 & 337 & $7.452^{06}$ \\
40.10 & 8.75 & 0.218 & 0.0044 & 228 & $1.263^{05}$ \\
48.70 & 10.80 & 0.222 & 0.0060 & 168 & $1.863^{05}$ \\
55.20 & 10.95 & 0.198 & 0.0073 & 137 & $2.393^{05}$ \\
70.30 & 11.56 & 0.164 & 0.0109 & 91 & $3.882^{05}$ \\
76.60 & 11.95 & 0.156 & 0.0127 & 79 & $4.609^{05}$ \\
80.00 & 12.30 & 0.154 & 0.0137 & 73 & $5.027^{05}$ \\
84.30 & 12.60 & 0.149 & 0.0150 & 67 & $5.582^{05}$ \\
\hline
\end{tabular}

The above table was derived from the crown-diameter and stem-diameter regressions, and was computed as follows: $C d=1.743+0.143 d b h$ (Daniellia oliverii); Growing space $(\mathrm{S})=\mathrm{Cd}^{2} \pi / 40000$ and limiting stocking $(\mathrm{N})=1 / \mathrm{S}$.

\section{DISCUSSION}

In all the data sets from the trees (Figure 1 and 2), there was more concentration of stem diameter at the upper diameter class $(15.00-40.00 \mathrm{~cm})$ than in the lower diameter class distribution $(41.00-50.1$ $\mathrm{cm}$ ); this may be as a result of high mortality or exploitation on the trees for socio-economic purposes 
by the rural communities. The result on the crown diameter class can be used as an important visual indicator of tree and forest trend (healthy or unhealthy) in the study area. Tree's crown is a major part of tree that can trap light for food production; trees with full and healthy crowns are generally associated with higher growth rates as a result of an increased rate for photosynthesis. When crowns become unhealthy, the rate of photosynthesis is reduced. These results described the current status and condition of the trees in the area, i.e. the crown conditions in the study area were healthy and free from high competition. This may be as a result of low population (declining in population due to deforestation without reforestation) of the tree species (open grown trees) or the soil condition of the area. The result is in accord with KENK (1993) and LAWRENCE et al., (2002), who stated that crown degradation is typically the result of past and present stressors such as insects, diseases, weather events, drought, senescence, and competition or other stand conditions and when severe enough, may result in tree mortality.

\section{Crown-Diameter and Stem-Diameter Regression Relationship}

Results shows on table 2 summarised linear, power, natural log regressions for the trees; the coefficients of determination differ among the models within the tree species in this study area, this may be attributed to the fact that almost all the sample trees were small in size with relatively small crown diameters (see Figures 1 and 2). $\mathrm{R}^{2}$ and RMSE in model 6 was better than model 4 and 5 but have lower F-ratio, with a residual and normal probability plots not well conformed to the regression analysis when compared with models 4 and 5 (see Table 2); while model 8, 9 and 10 have almost close $\mathrm{R}^{2}$ with lower Furnival index (FURNIVAL, 1961) (RMSE) which was better than model 4, 5, 6 and 7 .

The results on linear and power regressions (i.e. models 4 and 5) are in accord with FOLI et al., (2003) and LOCKHART, et al., (2005), stated that crown diameter and bole diameter relationship is sigmoid for forest grown trees. Crown expansion would be slow relative to early diameter growth as trees are crowded in dense young stands; as trees begin to express dominance, stem diameter growth increases almost linearly as crown expansion increases. When the tree reaches maturity, crown expansion essentially ceases while diameter continues to increase as photosynthesis is increasingly used for tree maintenance and support LOCKHART, et al., (2005).

The regressions line in models 4 and 5 for the species conforming to Dawkins type 2-behaviour i.e. 'straight line with a positive intercept' (LOCKHART, et al., 2005; ZUHAIDI, 2009) while models 6, 7, 9 and 10 exhibited the type 3-behaviour 'namely a straight line with a negative intercept' (FOLI et al., (2003)). He also reported that crown diameter and stem diameter equations should have positive intercepts, which suggests that crown diameter and stem diameter ratio decreases with tree size.

Based on models ranking and selection criteria, the regression analysis results (Table 2 and Figures 3 and 4) showed that crown diameter was better correlated with bole diameter in model 4 . Thus, model 4 was the best model because the model conformed to assumptions of regression analysis with positive coefficients, couple with its superiority in past research and ease of application (FOLI et al., 2003).

Linear crown diameter and bole diameter relationships with positive y-intercepts and coefficients behaviour described by LOCKHART, et al., (2005), stated that 'a possible depression in the relationship could occur at the upper end of the crown diameter and bole diameter relationship due to tree senility (age); such a depression is possible with $D$. oliverii at old age but none was found in this study, may be due mortality or over exploitation of the tree by the rural communities.

The best model (linear model 4) was fitted on independent (reserved) data for validation using T-test to test for significance at 0.05 level of significant; p-value (Figure 3) revealed no significant difference between the measured crown diameters (observed) and predicted values. The Pearson correlation coefficients was estimated to be $0.96 \%$ with $\mathrm{p}=0.31$ at one-tail and 0.62 two-tail. According to the results, the best model was the linear model which fitted best; power model was equally good and can sufficiently predict crown diameter from bole diameter. This result agreed with MUGO (2011), based on the data set from the study area i.e. the crown diameter and bole diameter relation is linear. Simple regression model (linear model) was used by LOCKHART, et al., (2005) to determine crown diameter and dbh relationship for six bottomland hardwoods species on Pittman island along Mississippi river; these results agreed with their results in the study area. While model 5 (power model) was used by ZUHAIDI (2009), in modelling crown and stem diameter relationship on 
plantation-grown on Dryobalanops aromatica in Bukit Lagong forest reserve (Malaysia) which happened to be the best because it explained the variation in crown diameter adequately and had the lowest standard error (RMSE); also, AVSAR and AYYILDIZ, (2005), settled on the power model to describe crown diameter and bole diameter relationships but based on the data from Makurdi-Nigeria, model 5 happen to do better among the other models (i.e. model 6-10).

\section{Growth Space Requirements for Daniellia Oliverii (Rolfe) Hutch and Daviz Tree in Makurdi- Nigeria}

Growth space requirements for the each tree species was determined based on the findings by FOLI $e t$ $a l$, (2003), who stated that growth space was associated with crown size. Therefore, using the calculated crown diameter $(\mathrm{Cd})$, the crown area (A) for each tree was estimated and expressed in hectare basis (Table 3); to improve production, fast growth and quality of tree species in the study area, individual tree in a stand must have unrestricted continuous free-growing space; this requires knowledge of maximum occupancy [stock] of sites with time. Thus, to control competition and ensure fast growth and high production/yields, this economic tree would require planting spacing of $4 \times 4$ meters in the study area; the results also provided a means of estimating the stocking per hectare $(\mathrm{N}$ $\mathrm{ha}^{-1}$ ) require for producing a complete canopy. This can be expressed as inverse of the growing space as is summarized in table 3 . It can be concluded that a dominant free-growing tree of D. oliverii with diameter of $48.7 \mathrm{~cm}$ would require a growing space of 0.006 with 168 trees as the stocking.

The result on growth space requirements showed that the model was more elastic between $18.7 \mathrm{~cm}$ and $48.7 \mathrm{~cm}$ and gradually decreased as the diameter size increased (see Table 3). The crown-stem diameter ratio is a measure of the efficiency of a tree to accumulate diameter at breast height per unit of crown area. The higher the ratio, the more efficient a tree species is at accumulating dbh (LOCKHART et al., 2005). In the study, D. oliverii tree was found to be efficient at accumulating stem diameter (Table 3). The results on ratio showed that for each meter of crown diameter in $D$. oliverii tree, $0.164 \mathrm{~cm}$ of stem diameter was accumulated as the highest efficient without serious crown interference or competition. Data in the present study represent a wider range of diameter classes (Figure 1). Furthermore, the forest in the present study was subject to a periodic harvesting and disturbance, which may have influenced the difference in the stem diameter and crown diameter ratios in the study area.

Stands with wider spacing in time, have larger average stem and crown diameter than similar stands with closer spacing; from table 3 above, the trees would require low densities for optimum planting, fast growth and high yield for the purpose of timber and non-timber forest products in the study area. This agreed with (CLUTTER et al., 1983), who stated that low densities are required to produce maximum diameter growth throughout the life of an even-aged stand.

\section{Conclusion}

Crown- bole diameter relationship helps to predict growth space requirements for optimum planting and estimation of stand density/stocking for establishing plantations and sustainable management of economic tree species. D. oliverii (Rolfe) tree would require low densities for optimum planting, fast growth and high yield for the purpose of timber and high densities for non-timber forest products in the study area; because low densities are required to produce maximum diameter growth throughout the life of trees stand which is applicable to the studied tree species as showed by the results obtained from the area. To maximize the use of land for timber and non-timber forest products purposes, the tree species would require growth planting spacing of $4 \times 4 \mathrm{~m}$ (for fencing pole and electric-pole). For maximum volume of timber, thinning should be administer at canopy closure; this is to create more spacing for continue growing until the trees only react minimal to thinning. The recommended planting spacing would enhance optimum planting, fast growth, high yield/production and control competition within each tree species. The forest in the present study was subject to periodic harvesting and disturbance, which may have influenced the difference in the stem diameter and crown diameter ratios among the species in the study area. Therefore, it is recommended that a similar study should be carried out in an undisturbed natural forest estate on the tree species for comparison of the growth space requirements for timber and non-timber forest products purposes (plantations establishment). 


\section{REFERENCE}

[1] Agera, S.I.N.; Agbidye, F.S. and Amonum, J. I. (2011): A survey of wood protection chemicals, tree kllers and sprayers in agrochemical stores within Makurdi metropolis, Benue state, Nigeria; Journal of research in forestry, wildlife and environmental, vol. 3 (2); pp.; 107-118.

[2] Ajaero C. (2007): A brand new image for Benue; In: Newswatch magazine, (Newswatch communication).

[3] Avsar, M.D. and V. Ayyildiz, (2005): The relationships between diameter at breast height, tree height and crown diameter in Lebanon cedars (Cedrus libani A. Rich.) of the Yavsan mountain, Kahramanmaras, Turkey, Pak. J. Biol. Sci., 8(9): 1228-1232.

[4] Bechtold, W.A.; Mielke, M.E. and SJ Zarnoch, S.J. (2002): Comparison of field methods and models to estimate mean crown diameter; Northern Journal of Applied Forestry; Vol. 19:177182.

[5] Clutter, J.L., Fortson, J.C., Pienaar, L.V., Brister, G.H., Bailey, R.L., 1983. Timber Management: A Quantitative Approach. Wiley, New York, p. 333.

[6] Colbert, K. C.; Larsen, D. R. and Lootens, J. R. (2002): Height-diameter equations for thirteen Midwestern Bottomland hardwood species; Northern Journal of Applied Forestry 19: 171- 176.

[7] Foli, E.G; Alder, D.; Miller, H.G. and Swaine, M.D. (2003): Modeling Growing Space Requirements for some Tropical Forest Tree Species; Forest Ecology and Management 173 (2003); pp. 79-88; www.elsevier.com/locate/foreco.

[8] Furnival, G.M. (1961): An index for comparing equations used in constructing volume tables. Forest Science 7: 337-341.

[9] Gering, L.R and D.M May. (1995): The relationship of diameter at breast height and crown diameter for four groups in Hardin County, Tennessee. Southern Journal of Applied Forestry 19:177-181.

[10] Goelz, J.C.G. (1996): Open-grown crown radius of eleven bottomland hardwood species: prediction and use in assessing stocking. South Journal of Applied Forestry 20:156-161.

[11] Helms, J.A. (ed.) (1998): The dictionary of forestry; Society of American Foresters, Bethesda, MD.210.

[12] Hemery, G.E., Savill P.S. and Pryor S.N, (2005): Applications of the crown diameter stem diameter relationship for different species of broadleaved trees. Forest Ecology Management, 215(3): 285-294.

[13] Kenk, G. (1993): Growth in "declining" forests of Baden-Wurttemberg (Southwestern Germany). In: Huettl, R.F.; Mueller-Dombois, D., eds. Forest decline in the Atlantic and Pacific region. New York: Springer- Verlag: 202-215.

[14] Kigomo, B.N., (1991): Crown and bole diameter relationship in Brachyleana huillensis and its application to silvicultural interventions. E. Afr. Agric. Forest. J., 57(1): 67-73.

[15] Kigomo, B.N., (1998): Morphological and growth characteristics in Brachyleana huillensis (Muhugu); some management considerations. Kenya J. Sci. (Series B), 11(1-2): 11-20.

[16] Kozak.A., and Smith J.H.G. (1993): Standards for evaluating taper estimating system .The forestry chronicle,69(4):438-444.

[17] Koziowski, T. Kramer, P., Pallardy, S. (1991): The physiological ecology of woody plants.

[18] Kunluvainen, T. (1991): Relationship between crown projected area and components of aboveground biomass in Norway spruce stands; empirical results and their interpretation; Forest Ecology Management, 40; 243-260.

[19] Lawrence, R.; Moltzan, B.; Moser, W.K. [2002]: Oak decline and the future of Missouri's forests. Missouri Conservationist. 63(7): 11-18.

[20] Lockhart, B.R.; Weih, C.R. and Smith, M.K., (2005): Crown Radius and Diameter at Breast Height Relationships for Six Bottomland Hardwood Species; Journal of the Arkansas Academy of Science, Vol.59; pp: 110-115.

[21] Mohamed O.A. and Ahmed E. (2014): Height Diameter Relationship Model for Acacia Nilotica in Riverine Forests - Blue Nile; Journal of Forest Products and Industries; Vol. 3(1); Pp: 50-55 ISSN: 2325-4513(Print) ISSN 2325 - 453x (Online). 
[22] Mugo, J.M.; Njunge, J.T. Malimbwi, R.E.; Kigomo, B.N.; Mwasi, B.N. and Muchiri, M.N. (2011): Models for Predicting Stem Diameter from Crown Diameter of Open Grown Trees in Sondu-Nyando River Catchment, Kenya; Asian Journal of Agricultural Sciences 3(2): 119-126; ISSN: 2041-3890.

[23] N. P. C. (National Population Commission, 2006): Population of local government in Benue state. Federal government of Nigeria gazette.

[24] Onyekwelu, J.C. (2005): site index curves for site quality assessment of Nauclea diderrichii monoculture plantations in Omo forest reserve, Nigeria; journal of tropical forest science; 17(4): $532-542$.

[25] Phillip, M.S. (1994): Measuring Trees and Forests. CAB International, Wallingford.

[26] Seibert U. (2007): Languages of Benue state, Nigeria; MSc. thesis; Languages Department of Languages and Linguistics, University of Jos.

[27] Smith, D. M. (1986): The Practice of silviculture, $8^{\text {th }}$ edition, wiley, New Yock.

[28] University of Agriculture Makurdi Physical Planning Manual, (1989)

[29] Zuhaidi, Y. A. (2009): Local Growth Model in Modeling the Crown Diameter of plantationGrown Dryobalanops aromatic; Journal of Tropical Forest Science 21(1); pp: 66-71. 